\title{
POSTCOMMUNIST CHARTERS OF RIGHTS IN EUROPE AND THE U.S. BILL OF RIGHTS
}

\author{
WOJCIECH SADURSKI*
}

I

\section{INTRODUCTION}

The Bill of Rights of the United States Constitution served as both a model and anti-model ${ }^{1}$ for the constitutionalization of citizens' rights in the new democracies emerging after the fall of communism in Central and Eastern Europe ("CEE"). The U.S. Bill of Rights served as a model at a general, abstract level, similar to the way in which it provided an example to Western European countries after the Second World War, thereby informing the "new constitutionalism" in Europe. . In contrast to traditional European constitutionalism, this new approach was influenced by three ideas that had long been commonplace in U.S. constitutionalism. First, a constitution cannot confine its scope to the regulation of the vertical and horizontal separation of powers; it is incomplete without an explicit written statement of citizens' rights that cannot be transgressed by any agent to whom the Constitution applies. ${ }^{3}$ Second, the provisions

Copyright (C) 2002 by Wojciech Sadurski

This article is also available at http://www.law.duke.edu/journals/65LCPSadurski.

* Professor in the Department of Law, European University Institute, Florence, Italy, and in the Faculty of Law, University of Sydney, Sydney, Australia.

1. I have borrowed this formula from Heinz Klug, Model and Anti-Model: The United States Constitution and the "Rise of World Constitutionalism," 2000 WIS. L. REV. 597. In his article, however, Professor Klug is concerned with the influence of the U.S. Constitution as a whole (and not just the Bill of Rights) on other countries of the world, such as the Philippines, id. at 599-600, Latin American countries, $i d$. at $601-02$, and some African states, $i d$. at 604 , and not specifically on postcommunist constitutions.

2. For further discussion of the "new constitutionalism" in Europe, contrasted to pre-World War II European constitutionalism, see generally AlEC STONE SWEeT, Governing WITH JudGeS: CONSTITUTIONAL POLITICS IN EUROPE 31, 37-38 (2000). For further discussion of the influence of "U.S. concepts of freedom" on constitutionalism in Europe, see generally Bojan Bugaric, Courts as Policy-Makers: Lessons from Transition, 42 HARV. INT'L L.J. 247, 251 (2001) (discussing how U.S. constitutional theory and practice increased European concerns with the protection of human rights); Anthony Lester, The Overseas Trade in the American Bill of Rights, 88 COLUM. L. REV. 537, 537 (1988); Andrzej Rapaczynski, Bibliographical Essay: The Influence of the U.S. Constitution Abroad, in CONSTITUTIONALISM AND RIGHTS: THE INFLUENCE OF THE UNITED STATES CONSTITUTION ABROAD 405, 435-36 (Louis Henkin and Albert J. Rosenthal eds., 1990).

3. For discussion of the importance of a written bill of rights, see William J. Brennan, Jr., Why Have a Bill of Rights?, 9 OXFORD J. LEGAL STUD. 425, 432 (1989). 
of the constitutional charter of rights apply directly to all state bodies ${ }^{4}$ regardless of statutory implementation; these constitutional rights are cognizable and enforceable by courts. Third, to be meaningful and truly paramount, constitutional rights should be a basis for declaring subconstitutional provisions invalid in cases of inconsistency.

These three principles, whose U.S. pedigree is undisputed, have generally been accepted in the constitutional designs of transitional postcommunist states. ${ }^{5}$ The attractiveness of these principles is not surprising: After a period of sham constitutions and charters of rights, constitution-makers in postcommunist countries needed firm doctrinal bases to convince their audiences-societies liberated from authoritarian regimes marked by high degrees of legal and constitutional nihilism - that their democratic and institutional commitments were genuine. Hence the appeal to a conception of constitutional rights that is as robust as possible-with rights having a firm textual anchor, being directly applicable to the people, and overriding lower laws in cases of inconsistency-becomes extremely appealing.

Yet the U.S. Bill of Rights is also an anti-model. When it comes to specific provisions of constitutional design as opposed to general, postcommunist constitution-makers have been much more inspired by post-Second World War European (continental) constitutionalism, with the German, French, and Italian constitutions serving as the more obvious prototypes of constitutional rights formulations than the U.S. example. Some reasons for this are obvious: The postcommunist $\mathrm{CEE}$ societies have much more in common with regard to tradition, culture, and social structure with Western Europe than with the United States. These similarities naturally extend to constitutional and legal culture as well. One obvious difference between the United States and Western Europe is the relatively low status of, and trust in, the judiciary in Europe, in contrast to the elevated position and prestige of the bench in the United States. ${ }^{6}$ This institutional difference has a strong effect upon the character of a constitutional charter of rights. The abstract nature and ambiguous language found in provisions of the U.S. Bill of Rights is seen by many U.S. lawyers as a virtue.? This high level of generality is well suited to a legal environment led by powerful and revered judges, endowed with the duty to translate vague and general state-

4. Whether constitutional charters of rights also apply to mutual relations among the citizens, that is, whether they have a "horizontal" dimension, is an issue which will not be discussed here.

5. For a distinction between the direct and indirect influence of the U.S. Constitution, see Ronald St.J. MacDonald, Constitutionalism and Rights: The Influence of the United States Constitution Abroad, 86 AM. J. INT'L L. 192, 196-97 (1992) (book review).

6. See Mauro Cappelletti, The Judicial Process in Comparative Perspective 51 (1989); MAURo CAPPElletTi \& William COHEN, COMPARATIVE CONSTITUTIONAL LAW: CASES AND MATERIALS 81-82 (1979); F.L. Morton, Judicial Activism in France, in JUDICIAL ACTIVISM IN COMPARATIVE PERSPECTIVE 133, 134-35 (Kenneth M. Holland ed., 1991) (comparing the low status of judges in France to that of judges in common law countries); Doris Marie Provine, Courts in the Political Process in France, in COURTS, LAw, AND POLITICS IN COMPARATIVE PERSPECTIVE 177, 178-80 (Herbert Jacob et al. eds., 1996) (same).

7. See Brennan, supra note 3 , at 426 . 
ments into specific articulations of rights. Conversely, the lower the prestige and authority of judges collectively, the greater the emphasis constitutionmakers place on framing constitutional rights as specifically as possible, with as narrow a margin of discretion for interpretation. Since judges, including judges of constitutional courts, are viewed with less trust in CEE countries than in the United States, it was clear to many drafters that the European approach to a constitutional charter of rights-attempting to enumerate all possible restrictions upon constitutional rights in the constitutional text, rather than leaving the task to judges ${ }^{8}$ - was preferred.

The newness of Western European constitutions was also an important factor. When looking for direct inspiration, constitution designers in postcommunist countries naturally preferred to follow the example of the forty- or fiftyyear-old constitutions of Western Europe rather than the 200-plus-year-old one of the United States. Moreover, the direct impact of constitutional experts and advisers, visiting newly democratic countries and dispensing their expertise and recommendations, has been more intensely felt from Western Europe than from the United States. This is not to say that CEE countries were fully deprived of the benefits of wisdom and advice from U.S. constitutional lawyers." Many such U.S. lawyers were prone to conclude, even on the basis of scant opportunities to get acquainted with local experience and tradition, that what a particular CEE country really needed bore a curious resemblance to the U.S. Constitution, and to a body of jurisprudence like that developed by the U.S. Supreme Court. ${ }^{10}$ But Western Europeans were closer geographically to the newly democratic states and proved much more persuasive. Hence, a U.S. scholar is correct to observe: "As exporters, advocates of the American model found that, instead of enjoying an unassailable, dominant status, they faced open competition from advocates of the German ... or other constitutional experiences." 11 Indeed, those other advocates proved to have significant advantage in this "competition." In particular, European bodies such as the Venice

8. See infra Part IV.

9. As a leading U.S. constitutionalist observed, perhaps not very generously, but realistically: "American constitutional lawyers ... were happy to cheer the fall of the Berlin Wall and to celebrate the rise of world constitutionalism with an orgy of junketeering to far-off places in need of legal lore." Bruce Ackerman, The Rise of World Constitutionalism, 83 VA. L. REV. 771, 772 (1997); see also A.E. Dick Howard, How Ideas Travel: Rights at Home and Abroad, in CONSTITUTION MAKING IN EASTERN EUROPE 9, 10 (A.E. Dick Howard ed., 1993) (stating, "Traffic is heavy between the United States and the emerging democracies.... [A]mericans who travel to consult on new constitutions are sometimes dubbed 'constitutional Johnny Appleseeds"').

10. For an example of such an approach, see BRUCE ACKERMAN, THE FUTURE OF LIBERAL REVOLUTION 99-101 (1992), and a harsh critique by Richard A. Posner, The Future of Liberal Revolution by Bruce Ackerman, 1 E. EUR. CONST. REV., Fall 1992, at 35, 36 (book review) (attributing to Ackerman's book an attitude of "good natured, if faintly patronizing, American universalism-the New World galloping to the rescue of the Old").

11. Klug, supra note 1, at 598; see also András Sajó, Universal Rights, Missionaries, Converts, and Local Savages, 6 E. EUR. CONST. REV., Winter 1997, at 44, 47. 
Commission $^{12}$ have been very active in monitoring constitutional developments in Central Europe, and in providing CEE countries with their advice. The advice has been, as one would expect, in accordance with what is perceived as "the European constitutional heritage" ${ }^{" 13}$ rather than the U.S. tradition. The fact that nearly all postcommunist countries after transition quickly joined the Council of Europe ${ }^{14}$ became signatories to the European Convention of Human Rights ("ECHR"), ${ }^{15}$ and that most of them aspire to membership in the European Union $^{16}$ was undoubtedly strengthened by the attractiveness of the models used in Western Europe.

It is therefore no wonder that the constitutional charters of rights adopted after the fall of communism ${ }^{17}$ bear little resemblance to the U.S. Bill of Rights, and appear much more similar to charters of rights in Western European constitutions and in the ECHR. There are several main differences. First, in contrast to the U.S. Bill of Rights, postcommunist constitutions have included in their charters of rights a number of socioeconomic rights. These provisions place "positive" requirements upon states, often resembling general guidelines for governmental policy, and not just negative duties with the purpose of avoiding harm to the citizens in constitutionally specified ways. Second, the catalogues of rights are accompanied, in most charters of rights, by constitutional duties imposed upon citizens. Third, in contrast to the U.S. Bill of Rights, which articulates particular rights in an ambiguous fashion left open to interpretation, postcommunist constitutions (as well as all continental European constitutions and the ECHR) explicitly spell out the criteria for legislative restrictions on

12. The full name of the Venice Commission is the European Commission for Democracy through Law. The Venice Commission (as it is generally known) was set up in March 1990, under the auspices of the Council of Europe, with the specific aim of rendering assistance, through expert advice, in the field of constitution-drafting (and related issues, such as drafting of electoral laws) in newly established states of Central and Eastern Europe. It boasts that it "has played a leading role in the adoption, in eastern Europe, of constitutions that conform to the standards of Europe's constitutional heritage," "Introduction," available at http://www.venice.coe.int/site/interface/english.htm (last visited Apr. 4, 2002).

13. $I d$.

14. The only states that are considered in this article (for their list, see Appendix) which are not members of the Council of Europe are Belarus, Bosnia and Herzegovina, and the Federal Republic of Yugoslavia. In this article, I am also considering the constitutions of Serbia and Montenegro, which are formally parts of the Federal Republic of Yugoslavia. Bosnia and Herzegovina and Yugoslavia, however, have a status of "special guests" to the Parliamentary Assembly of Council of Europe. ECHR.

15. All CEE countries that are members of the Council of Europe have signed and ratified the

16. The following CEE countries are now formally being considered for membership in the European Union (EU): Hungary, Poland, Slovenia, the Czech Republic, and Estonia (all invited in 1997 to begin accession negotiations in 1998); Slovakia, Bulgaria, Lithuania, Latvia, and Romania (all invited in 1999 to begin accession negotiations in 2000). While all of these countries had adopted their new constitutions, or at least amended their old constitutions by injecting into them chapters on citizens' rights (as was the case with Poland and Hungary) well before the opening of formal negotiations with the EU, the project of their joining the European Community (as it was then called) was always an important part of the strategic political vision of most democratic forces after the transformation in CEE.

17. The discussion in this paper takes into account constitutions in all twenty-two postcommunist countries of the CEE countries. For a list of these constitutions, see the Appendix. 
rights in their texts. Fourth, in postcommunist constitutions the supremacy of constitutional rights over statutory provisions is safeguarded by judicial review exercised by a facial challenge to newly adopted laws in specialized tribunalsconstitutional courts - rather than by ordinary courts in the process of deciding specific cases and controversies.

The first three features described above will inform the structure of this article. Part II will address the ways of (and controversies surrounding) constitutionalizing socioeconomic rights; Part III will analyze the place of citizens' duties in the constitutions of new postcommunist democracies; and, in Part IV, constitutional standards of permissible restrictions on citizens' rights will be examined. The fourth point above, that of the emergence of centralized and abstract judicial review, in contrast to the U.S. decentralized and concrete review, deserves separate treatment and raises specific institutional questions that I have discussed elsewhere. ${ }^{18}$

One preliminary caveat - there is no single model postcommunist CEE constitution. While CEE constitutions display a number of common characteristics contrasted with the U.S. Bill of Rights, there are very important variations in approaches to each of the three features mentioned above. One should be wary of constructing a composite model of a postcommunist constitution. Therefore, in this article I will attempt to emphasize rather than gloss over the variety and diversity of models of constitutional design chosen in CEE countries.

\section{II}

\section{SOCIOECONOMIC RIGHTS}

The most striking contrast between the U.S. Bill of Rights and postcommunist constitutional charters of rights is the absence in the former, and the inclusion in the latter, of catalogues of so-called "positive," socioeconomic rights. ${ }^{19}$

18. Wojciech Sadurski, Conclusions: On the Relevance of Institutions and the Centrality of Constitutions in Post-Communist Transitions, in DEMOCRATIC CONSOLIDATION IN EASTERN EUROPE, VOL. I: INSTITUTIONAL ENGINEERING 455, 456-57, $472-74$ (Jan Zielonka ed., 2001); Wojciech Sadurski, Rights-Based Constitutional Review in Central and Eastern Europe, in SCEPTICAL ESSAYS ON HUMAN RIGHTS LAW 315-33 (Tom Campbell et al. eds., 2001); Wojciech Sadurski, Judicial Review, Separation of Powers and Democracy: The Problem of Activist Constitutional Tribunals in Postcommunist Central Europe, 3 StUdi Politici 93 (1999); WoJCIECH SADURSKI, POSTCOMMUNIST CONSTITUTIONAL Courts in SEARCh of Political Legitimacy (EUI Working Paper LAW No. 2001/11, 2001). For the best discussion of postcommunist judicial review from the perspective of a U.S. legal scholar, see generally HERMAN SCHWARTZ, THE STRUgGle FOR CONSTITUTIONAL JUSTICE IN POSTCOMMUNIST EUROPE (2000). For the most comprehensive and up-to-date survey of constitutional judicial review in CEE countries, see GIUSTIZIA COSTITUZIONALE E SVILUPPO DEMOCRATICO NEI PAESI DEll'Europa CENTRO-ORIENTAle [CONSTITUTIONAL Justice AND DEMOCRATIC DEVELOPMENT IN THE COUNTRIES OF CENTRAL AND EASTERN EUROPE] (Giuseppe de Vergotini ed., 2000). See also ReTt R. LUdWIKOWSKI, CONSTITUTION-MAKING IN THE REGION OF FORMER SOVIET DOMINATION 212-15 (1996) (discussing judicial review in the new East-Central European constitutions).

19. Identification of socioeconomic rights with "positive" rights involves an oversimplification. The positive/negative distinction does not correspond to a distinction between socioeconomic and civilpolitical rights: Some civil rights may require a positive state action, and some socioeconomic rights 
Where the U.S. Bill of Rights is concerned, all attempts to read welfare rights into it have been consistently and emphatically resisted by the Supreme Court. ${ }^{20}$ In the oft-quoted words of Seventh Circuit Court of Appeals Judge Richard A. Posner, the official interpretation of the Bill of Rights is of "a charter of negative rather than positive liberties" motivated not by the concern "that government might do too little for the people but that it might do too much to them." ${ }^{21}$ Regardless of philosophical discussions about whether such rights properly belong in constitutions, the omission of such rights was never a plausible political option for constitution-makers after the fall of communism. For one thing, the economic legacy of communism was widespread poverty, deprivation, and a lack of economic, cultural, and educational opportunities. Omitting socioeconomic rights from the new constitutions would have sent a signal to the CEE communities that the political elites who emerged after the fall of communism were insensitive to the plight of common people who had been dramatically affected by these countries' dire economic situation. In addition, the impact of liberal political forces ("liberal" in the European, free-market sense) which may have been reluctant on ideological grounds to constitutionalize broad catalogues of socioeconomic rights, has been relatively weak, and the political weight of social democrats and Christian Democrats in the region has been quite strong. ${ }^{22}$ These parties, as well as nonideological peasant parties, had a strong stake in infusing the constitutional charters of rights with symbolic statements of their attachment to the idea of an activist state protecting the citizens against economic calamities. To some degree, this was also an ideological legacy of communism ${ }^{23}$ which generated strong welfare expectations. The idea that citizens are entitled to a certain, albeit often miserably low, standard of living, work, recreation, and education has proved particularly well entrenched in mass consciousness.

But it is one thing to say that the inclusion of socioeconomic rights was politically the only plausible option and another to say that it was unproblematic. Far from it-in the constitutional debates within postcommunist states and held by outside observers, some important objections were raised to the idea of constitutionalizing welfare rights. ${ }^{24}$ It is important to emphasize that the reasons for the rejection of the idea of constitutional welfare rights was not grounded on a

may demand state non-interference with individual action. However, this is not the place to discuss this issue in detail, and in the main text I am merely following conventional terminology.

20. See, e.g., San Antonio Indep. Sch. Dist. v. Rodriguez, 411 U.S. 1, 37 (1973) (finding no fundamental right to public education); Lindsey v. Normet, 405 U.S. 56, 74 (1972) (finding no fundamental right to adequate housing).

21. Jackson v. City of Joliet, 715 F.2d 1200, 1203 (7th Cir. 1983).

22. For a discussion of different "political orientations" influencing constitution-making in postcommunist Poland, see Piotr Winczorek, Axiological Foundations of the Constitution of Poland, 1997 ST. LOUIS-WARSAW TRANSATLANTIC L.J. 59, 61-62.

23. Jean-Marie Henckaerts \& Stefaan Van der Jeught, Human Rights Protection Under the New Constitutions of Central Europe, 20 LOY. L.A. INT'L \& COMP. L. REV. 475, 491 (1998).

24. See Wojciech Sadurski, Rights and Freedoms Under the New Polish Constitution, in THE RULE OF LAW AFTER COMMUNISM 176, 180-83 (Martin Krygier \& Adam Czarnota eds., 1999). 
rejection of welfare policies. ${ }^{25}$ The basic idea was that there is a non sequitur between advocating a welfare policy and advocating the elevation of welfare rights to a constitutional level. Some participants in this debate, by comparing generous welfare states with no socioeconomic rights in their constitutions to countries that have an appalling welfare situation but impressive catalogues of constitutional socioeconomic rights, went one step further and asserted an inverse relationship between socioeconomic rights being in a constitution and the existence of a welfare safety net. For example, Ulrich Preuss, a careful student of postcommunist constitutionalism, noted with respect to $\mathrm{CEE}$ constitutions, "it is striking that a number of [constitutional] pledges-be they state goals or social rights-increase in inverse proportion to the extent that these countries are able and prepared to establish a welfare state. ..."26

Opponents of constitutional welfare rights may or may not have been advocating broad welfare policies. Practice around the world shows that there is no tight connection between how "generous" social rights are in a constitution and how generous social welfare policy is. Those opponents of constitutional welfare rights (and the author is one of them $)^{27}$ were concerned that, once a welfare right is written into a constitution, even if subject to various provisions about nonjusticiability, there is nothing that will disable a constitutional court from scrutinizing a government policy or a new law under the standard of this constitutional provision. ${ }^{28}$ Therefore, this practice may serve as a basis for displacing choices made by legislative and executive branches. Thus, the primary reason for disapproving of constitutional welfare rights is that they will produce an unfortunate institutional shift in the separation of powers and will allow (indeed, require) constitutional judges to decide matters in which they have neither qualifications nor political authority-essentially, an institutional-competence argument. $^{29}$

25. For a general discussion, see Wiktor Osiatynski, Rights in New Constitutions of East Central Europe, 26 COLUM. HuM. RTS. L. REV. 111, 138-45 (1994); Cass Sunstein, Against Positive Rights, 2 E. EUR. CONST. REV., Winter 1993, at 35, 36. For a good statement of argument in favor of constitutional socioeconomic rights, see Herman Schwartz, In Defense of Aiming High, 1 E. Eur. CONST. REV., Fall 1992 , at $25-27$.

26. Ulrich K. Preuss, Patterns of Constitutional Evolution and Change in Eastern Europe, in CONSTitutional Policy ANd Change in EuRoPe 95, 103 (J.J. Hesse \& N. Johnson eds., 1995); see also Jon Elster, The Impact of Rights on Economic Performance, in WESTERN RIGHTS? POSTCOMMUnist ApPlicATiOn 347 (A. Sajo ed., 1996).

27. See Sadurski, supra note 24 .

28. Preuss, supra note 26, at 101 ("Both social rights and state goals [when entrenched in constitutions] increase the power of the executive-which has the resources to design and to implement particular policies - and that of the courts-which make the final decision about the constitutional duties of the government-at the expense of the democratic authority of the parliament.").

29. Id.; Jerzy Ciemniewski, Sejm i Senat w projekcie Konstytucji RP [The Sejm and the Senate in the Draft Constitution of the Republic of Poland], in OCENA PROJEKTU KONSTYTUCJI RP [AN EVAluation of THE DRAFT CONSTITUTION OF THE REPUBlic OF POLAND] 37, 41-42 (Jozef Krukowski ed., 1996); Wiktor Osiatynski, Social and Economic Rights in a New Constitution for Poland, in WESTERN RIGHTS? POST-COMMUNIST APPLICATION 233, 262-69 (A. Sajo ed., 1996); Andrzej Rapaczynski, Constitutional Politics in Poland: A Report on the Constitutional Committee of the Polish Parliament, in CONSTITUTION MAKING IN EASTERn Europe 93, 107-08 (A.E. Dick Howard ed., 1993). 
A second reason for not including socioeconomic rights was the fear of contaminating the entire charter of rights by under-enforcement of socioeconomic rights. $^{30}$ These rights are, by their nature, under-enforceable. The fear was that a habit of tolerance for under-enforcement of some rights can erode a rigid commitment to enforcement of all other rights, including civil-political rights. Finally, it was claimed that, while statutory welfare rights may be a good thing, putting them in the constitution is wrong because the very nature of a constitution is meant to restrain legislators (and indirectly, the electorate) against likely, pernicious temptations. ${ }^{31}$ Constitutional rights are seen primarily as restraints upon human nature. In the context of CEE constitutions, Cass Sunstein claimed that elevating welfare rights to a constitutional level may promote attitudes of welfare-dependency and become a counterincentive to self-reliance and individual initiative. ${ }^{32}$ But once one explicitly spells out this rationale, one immediately sees why it is extremely unlikely that any actual constitutionmaking process will follow its logic. It is politically almost an impossible proposition because it would require the constitution-makers to propose-and enact-ideas explicitly contrary to conventional societal norms.

It is, therefore, not surprising that, in virtually all postcommunist constitutions, ${ }^{33}$ we find enumerated lists of socioeconomic rights (some broad, some narrow), and that any attempts at relegating them to a status of "tasks of state," which would clearly have implied that they not be seen as rights sensu stricto, generally failed. ${ }^{35}$ One such heroic attempt should be acknowledged: the 1992 "Presidential" (so-called because it was formally proposed by then-President Lech Walesa) draft of the constitutional Charter of Rights and Freedoms in Poland. ${ }^{36}$ It clearly distinguished "Social and Economic Rights and Freedoms"

30. See, e.g., Jon Elster, Constitution-Making in Eastern Europe: Rebuilding the Boat in the Open Sea, 71 PUB. ADMIN. 169, 198 (Spring/Summer 1993).

31. Sunstein, supra note 25 , at 35,36 .

32. Id. at 37 .

33. The only exception is the Constitution of Bosnia and Herzegovina, which does not contain any socioeconomic rights except for the right to education.

34. This is a construction adopted in, inter alia, the Spanish Constitution, where "Guiding Principles of Economic and Social Policy" (arts. 39-52) are distinguished from "Rights and Freedoms" (arts. 14-38). See also Ireland ("Directive Principles of Social Policy," IR. CONST. art. 45) and India ("Directive Principles of State Policy," INDIA CONST. arts. 36-41).

35. There are some minor exceptions. The Albanian Constitution has a lengthy list of "Social Objectives" (art. 59) that impose upon the government such tasks as aiming for full employment, meeting housing needs, and achieving the highest possible standards of health care (art. 59(1)), with a proviso that the fulfillment of these objectives cannot be claimed directly in court (art. 59(2)). However, these tasks are in addition to a number of socioeconomic rights which escape the latter proviso, such as "the right to earn the means of living" (art. 49(1)), the right to social security (art. 52 (1)), the right to health care (art. 55 (1)), and the right to education (art. 57 (1)).

36. The Polish text was published in RzeczPospolita [The Republic], Nov. 15, 1992. For an English translation, see Draft of the Charter of Rights and Freedoms, 1996 ST. LOUIS-WARSAW TRANSATLANTIC L.J. 73 (Stanislaw Frankowski trans.). For a useful discussion, see generally Stanislaw Frankowski, Lech Walesa's Draft of the Charter of Rights and Freedoms: An Overview, 1996 ST. LOUIS-WARSAW TRANSATLANTIC L.J. 65; Wiktor Osiatynski, A Bill of Rights for Poland, 1 E. EuR. CONST. REV., Fall 1992, at 29 (discussing the drafting and provisions of Walesa's proposed charter of 
(including a right to education, right to labor safety, right to medical protection, right to social welfare, and freedom of work) from "Economic, Social and Cultural Obligations of Public Authorities" (including, among other things, improvement of working conditions, full employment, aid to families, and medical care beyond the basic level). ${ }^{37}$ There also was an explicit statement that the latter "obligations" are to be performed by public authorities "depending upon their economic resources." ${ }^{38}$ This was meant to convey an idea that provisions on "socioeconomic tasks" applied to governmental actions and aspirations, rather than to determinate results. As a result, no pretense was made that these tasks and aspirations described a range of constitutional "rights." This project, however, never became law.

In consequence of these theoretical and political discussions, and of differences in local circumstances, there is a variety in the catalogues of socioeconomic rights and in their status within postcommunist constitutions of CEE countries. Three fundamental socioeconomic rights that figure most prominently in these constitutions are social security, health care, and education. Nearly all of the constitutions of the region contain broad provisions for rights to social security, either for all those unable to work or for all those in material need. ${ }^{39}$ The latter group is sometimes defined as those that have no other means of support. ${ }^{40}$ Many of these social security provisions go on to delineate specific subcategories of people who could be subsumed under the general notion of persons unable to work. These subcategories include the old, ${ }^{41}$ the $i l l,^{42}$ the disabled, ${ }^{43}$ those who have lost their breadwinner, ${ }^{44}$ and those who have been widowed or orphaned. ${ }^{45}$ In contrast to these constitutions with "generous" provi-

rights); Andrzej Rzeplinski, The Polish Bill of Rights and Freedoms: A Case Study of ConstitutionMaking in Poland, 2 E. EUR. CONST. REV., Summer 1993, at 26 (discussing the absence of political pressure for prompt introduction of a bill of rights). This constitutional draft was eventually aborted and disowned by President Walesa himself.

37. Draft of the Charter, supra note 36 , at ch. V.

38. Id. at art. 48.

39. Alb. Const. art. 52; Belr. Const. art. 41(1); Croat. Const. art. 57; Czech. Rep. CHARTER art. 26; EST. CONST. art. 28; Hung. CONST. art. 70E; LAT. CONST. art. 109; LiTH. CONST. art. 52; Mold. COnST. art. 47; POL. CONST. art. 67; RoM. CONST. art. 43; SLOVK. CONST. arts. 35, 39; UKR. CONST. art. 46; YUgOSLAVIA CONST. art. 58; MONT. CONST. art. 55; SERB. CONST. art. 39. art. 39 .

40. E.g., Pol. Const. art. 67; Yugoslavia Const. art. 58; Mont. Const. art. 55; Serb. Const.

41. Alb. CONST. art. 52; Belr. COnST. art. 47; Est. CONST. art. 28; Hung. CONST. art. 70E; LAT. CONST. art. 109; Lith. CONST. art. 52; MOLD. CONST. art. 47(2); POL. CONST. art. 67; SLOvK. CONST. art. 39(1); UKR. CONST. art. 46.

42. Belr. Const. art. 47; Hung. COnSt. art. 70E; LiTh. COnST. art. 52; Mold. Const. art. 47(2); POL. CONST. art. 67.

43. Belr. Const. art. 47; CroAt. CONST. art. 57; Hung. CONST. art. 70E; LAT. CONST. art. 109; Lith. CONST. art. 52; MOLD. CONST. art. 47(2); POL. CONST. art. 67; ROM. CONST. art. 46; SLOVK. CONST. art. 38(1); UKR. CONST. art. 46.

44. Belr. CONST. art. 47; EST. CONST. art. 28; LiTh. CONST. art. 52; SlOvK. CONST. art. 39(1); UKR. CONST. art. 46.

45. HUNG. CONST. art. 70E (discussing widowhood and orphanhood); LITH. CONST. art. 52 (discussing widowhood); MOLD. CONST. arts. 47(2) (discussing widowhood), 49(3) (discussing orphanhood). 
sions, a small minority of the constitutions in the region ${ }^{46}$ have only narrowly drafted provisions for social security, while two have no such provision at all. ${ }^{47}$ A right to health care has been proclaimed very "generously" (with free health care for all) in twelve constitutions of the region $;^{48}$ in some constitutions, health care is only a right conferred upon some categories of people, such as the elderly, children, and pregnant women. ${ }^{49}$ Five constitutions delegate to lawmakers the task of determining who will obtain free health care. ${ }^{50}$ Two constitutions cautiously provide a right of all to health insurance rather than to actual health care. ${ }^{51}$ Interestingly, the Hungarian Constitution proclaims a right for all those living in the territory of Hungary "to the highest possible level of physical and mental health," ${ }^{52}$ a guarantee which deftly evades any possible challenges because of the vagueness and indeterminacy of the term "highest possible level." The third right, that to free education, is recognized universally, though the level of constitutionally-mandated free education varies: A free education is guaranteed up to the university level in nine constitutions, ${ }^{53}$ up to the secondary level in five constitutions, ${ }^{54}$ and up to a primary level in five constitutions in the region. ${ }^{5}$

Among other socioeconomic rights, the most frequently mentioned are those which relate to working conditions, including a right to choose one's own profession, a right to safe conditions at work, to "adequate pay," to guaranteed leisure time, and to special protection for certain specified categories of employees (women, the young, the old) in the workplace. Without going into detail, the analysis shows that ten constitutions have a very broad list of those

46. Russia, Bulgaria, Macedonia, and Slovenia all include provisions for social security. The Russian Constitution (art. 39) provides for social security in cases of old age, illness, disability, and loss of breadwinner. The Bulgarian Constitution (art. 51) provides for social security only in cases of old age, disability, or temporary unemployment. The Macedonian Constitution only provides for social security in cases of temporary unemployment (art. 32) and then says all other social security rights will be determined by law (art. 34). The Slovenian Constitution (art. 50) provides that all those who fulfill the conditions laid down by law will receive social security benefits.

47. Georgia, and Bosnia and Herzegovina.

48. Belr. CONST. art. 45; CroAt. CONST. art. 58; CZECH. ReP. CHARTER art. 31; Est. CONST. art. 28; LAT. CONST. art. 111; Lith. CONST. art. 53; MACED. CONST. art. 39; Mold. Const. art. 36; ROM. CONST. art. 43; RUSS. CONST. art. 41; SLOVK. CONST. art. 40; UKR. CONST. art. 49.

49. Pol. CONST. art. 68; SERB. CONST. art. 30.

50. Bulg. Const. art. 52; Slovn. Const. art. 51; Yugoslavia Const. art. 60; Mont. Const. art. 55; SERB. CONST. art. 30.

51. Bulg. CONST. art. 52; GEOR. CONST. art. 37.

52. HunG. CONST. art. 70D.

53. Belr. CONST. art. 49; GeOr. CONST. art. 35; Lith. CONST. art. 41; Mold. Const. art. 35; Pol. CONST. art. 70; Rom. Const. art. 32; Russ. COnST. art. 43; SlOvN. CONST. art. 57; UkR. CONST. art. 53.

54. Alb. Const. art. 57; Bulg. Const. art. 53; Czech. Rep. Charter art. 33; Lat. Const. art. 112; SLOVK. CONST. art. 42.

55. CROAT. CONST. art. 65; HUNG. CONST. art. 70F (although it also guarantees financial support to all students); MACED. CONST. art. 44; Yugoslavia CONST. art. 62; MONT. CONST. art. 62. Two constitutions are unclear about the specific level at which free education is guaranteed: The Serbian Constitution mentions all "regular education" (art. 32), and the Estonian Constitution provides for such a right to "school-age children" (art. 36). 
work-related rights. ${ }^{56}$ Other assorted socioeconomic rights include the protection of the family, motherhood, and/or childhood (fourteen constitutions), ${ }^{57}$ training for the disabled (eight) ${ }^{58}$ protection of culture (thirteen), ${ }^{59}$ and a right to a good environment (thirteen). ${ }^{60}$ Considering the catastrophic housing situation in most of these countries, not surprisingly, only four constitutions explicitly proclaim a right to adequate housing, ${ }^{61}$ with two others listing it as an aim of the state rather than as an enforceable right. ${ }^{62}$

To sum up the textual analysis of the catalogues of socioeconomic rights, one can establish a simple taxonomy of the constitutions as falling into the following categories:

(1) the nine most "generous" constitutions which list comprehensive social security, education, health care, work protection rights, and other socioeconomic rights; ${ }^{63}$

(2) seven constitutions which have limited social security, education, and health care rights, but good work protection guarantees, and many other socioeconomic rights; ${ }^{64}$

(3) three constitutions which provide for good social security, education, and healthcare rights, but only a limited number of the other rights ${ }^{65}$ and

(4) two constitutions with very few socioeconomic rights. ${ }^{66}$

At this stage, three preliminary conclusions are in order. First, postcommunist constitutions are, overall, "rich" in socioeconomic rights. If one imagines a continuum in world constitutionalism based upon the "generosity" of dispensing socioeconomic rights, postcommunist constitutions are approaching the pole that provides the maximum number of constitutional rights. Second, the range of local variety is not all that great. If one ignores two "aberration" cases (Bosnia and Herzegovina and Georgia), and perhaps also three Baltic states, then the degree of diversity is relatively small. Third, and most important, there is Serbia.

56. Belarus, Hungary, Poland, Romania, Russia, Slovakia, Ukraine, Yugoslavia, Montenegro, and

57. Bulgaria, Croatia, Czech Republic, Estonia, Georgia, Hungary, Lithuania, Macedonia, Moldova, Poland, Russia, Slovenia, Montenegro, and Serbia.

58. Albania, Bulgaria, Croatia, Moldova, Poland, Romania, Slovenia, and Serbia.

59. Albania, Belarus, Bulgaria, Croatia, Czech Republic, Georgia, Lithuania, Macedonia, Poland, Russia, Slovenia, Ukraine, and Montenegro.

60. Belarus, Bulgaria, Croatia, Czech Republic, Georgia, Hungary, Moldova, Russia, Slovakia, Slovenia, Ukraine, Montenegro, and Serbia. In addition, five other constitutions establish a good environment as an aim for the state, though not enforceable as a right.

61. BELR. CONST. art. 48; RUSS. CONST. art. 40; SLOVN. CONST. art. 78; UKR. CONST. art. 47.

62. Alb. CONST. art. 59; POL. CONST. art. 75.

63. Belarus, Croatia, Czech Republic, Moldova, Poland, Romania, Russia, Slovakia, and Ukraine.

64. Bulgaria, Hungary, Macedonia, Slovenia, Yugoslavia, Montenegro, and Serbia.

65. Three Baltic states: Estonia, Latvia, and Lithuania. In fact, Lithuania falls in between this and the first category, with a middling number of work-protection and other rights.

66. Bosnia and Herzegovina, and Georgia. 
no discernible variable that would significantly account for these diversities. Not a single significant factor can persuasively explain the taxonomy suggested above-neither the stage of economic growth, nor the adopted strategy of development, nor the strength of postcommunist political forces, nor the heritage of belonging to the former U.S.S.R., nor the speed with which the constitution was created, nor the realistic prospect of admission to the EU, and so on. For instance, category (1) (the most "generous" constitutions) includes both the relatively affluent (Czech Republic, Poland) and the poorest (Moldova, Ukraine) countries of the region; those countries which adopted economic "shock therapy" in transition to a free market economy (Poland) and those that failed to adopt free-market measures (Belarus); those countries where postcommunist parties have been relatively marginalized (Czech Republic) and those where they have maintained their grip on power for a reasonably long time (Belarus, Slovakia); those that adopted constitutions soon after the transition (Slovakia) and those that took a long time to do so (Poland). Similar points can be made about category (2). In other words, there is no meaningful correlation between the "generosity" of catalogues of rights in a constitution and the objective circumstances of that country. Apart from everything else, this confirms a proposition that the constitutionalization of welfare rights has little or no effect upon the actual welfare policy of the government, though it may have an effect upon the institutional system of separation of powers.

This last effect-and more particularly, enhancing the powers of constitutional courts by bringing them into the making of social policy-is as much a matter of the actual catalogue of socioeconomic rights as of their constitutional status compared to other, more "traditional" rights. This is why it is important to study not only the catalogues of rights, but also the ways in which postcommunist constitutions handle the constitutional weight of socioeconomic rights compared to other constitutional rights.

From this point of view, one can distinguish three categories of constitutions. The first group, by far the largest, contains those constitutions that do not draw any meaningful distinctions between socioeconomic and all other rights. In the fifteen constitutions belonging to this category, ${ }^{67}$ no differentiation is made as to the enforceability of socioeconomic versus civil-political rights. In some of these constitutions, the two types of rights are even lumped together in the same subdivision of the constitutional text. ${ }^{68}$ The second category contains two constitutions: those of the Czech Republic and Slovakia (not surprisingly, considering that their respective bills of rights originate from one and the same text). ${ }^{69}$ Here, a clear separation of socioeconomic rights from the other rights is

67. Belarus, Bulgaria, Croatia, Estonia, Georgia, Hungary, Latvia, Lithuania, Macedonia, Romania, Russia, Ukraine, Yugoslavia, Montenegro, and Serbia.

68. For example, in Hungary.

69. In January 1991, the federal parliament of Czechoslovakia adopted the Charter of Fundamental Rights and Freedoms as a constitutional act. Even before the formal dissolution of the federation, two republics adopted slightly different legal strategies towards the Charter in their respective constitu- 
achieved by a general clause $\mathrm{e}^{70}$ which states that a number of specifically enumerated rights (that include most socioeconomic rights) can be claimed only within the limits of the laws implementing these rights-provisions. Hence, in contrast to all other rights unaffected by this general limiting clause, and which can only be restricted in accordance with constitutionally established criteria, socioeconomic rights are subject to legislative restrictions over which the (ordinary) legislator has wide discretion. This largely limits the possibility of mounting constitutional challenges to laws and policies under these rights. Also, it effectively, though not formally, reduces the weight of these rights to the weight of constitutionally established state targets or aims-politically binding upon the legislature and the executive, but not judicially enforceable.

It should be noted that, in the first category of constitutions (those with no distinction between socioeconomic and other rights), one can also find particular provisions which establish that practical details of certain rights shall be decided by law. For example, a Russian constitutional provision guaranteeing a right to social security is accompanied by a proviso that the details of state pensions and social benefits shall be established by laws. ${ }^{71}$ This, however, is different from a general clause (in Czech and Slovak fashion) which conditions enforceability of a right upon a legislative choice. Indeed, both the Czech and Slovak constitutional documents contain some rights which refer to laws that establish the details of the right, yet are not covered by the general limiting clause. $^{72}$

The third group is a hybrid category which combines the first and second solutions. In four constitutions in the region, ${ }^{73}$ we find a mixture of socioeconomic rights that are directly enforceable and those that are left for legislative discretion that can be seen as targets of the state. The Polish Constitution serves as an example. It contains a general limiting clause, similar to the one in the Czech Charter and the Slovak Constitution, but it also has a limiting clause that applies only to a select number of socioeconomic rights. Thus, these rights (which include the rights to a minimum wage, to full employment, and to aid to disabled persons) "may be asserted subject to limitations specified by law." On the other hand, the constitution lists a number of socioeconomic rights to which the general limiting clause does not apply, even if they have their own clauses attached which delegate to the legislature the duty to determine the scope and form of implementation of the right (a right to social security ${ }^{75}$ is an

tions: The Slovak Republic incorporated the Charter into its constitution (of September 1992) while the Czech Constitution (of December 1992) stated that the Charter formed a part of the constitutional order of the republic. CZECH REP. CONST. art. 112(1); SLOVK. CONST. arts. 11-54.

70. CZECH. REP. CHARTER art. 41; SLOVK. CONST. art. 51.

71. RUSS. CONST. art. 39.

72. E.g., CZECH. REP. CHARTER arts. 32(5)-(6) (providing assistance to parents raising their children); SLOVK. CONST. art. 43(2) (providing right of access to the cultural heritage).

73. Albania, Moldova, Poland, and Slovenia.

74. POL. CONST. art. 81.

75. Id. at art. 67(1). 
example). The fact that these particular socioeconomic rights were deliberately left outside the scope of control of the general limiting clause suggests that they are seen as fully enforceable rights.

Overall, the survey above shows that nearly all postcommunist constitutions ignore a distinction in status between civil and political rights on the one hand and socioeconomic rights (either all constitutional socioeconomic rights, or at least a significant number of these rights) on the other. This is a messy arrangement. Pretending that socioeconomic rights may be enforceable in exactly the same way as rights to freedom of speech or to vote creates expectations which cannot be fulfilled. It also brings the courts into complex policymaking and threatens to dilute the enforceability of civil and political rights. As a result, there is tension between constitutional texts and what one observer correctly perceived as "a growing sensitivity in East-Central Europe that social and economic rights should be treated differently from political rights and citizens' freedom." ${ }^{, 76}$ In some of the countries of the region, the task of drawing the necessary distinctions between various categories of rights has been undertaken by constitutional courts who are acting as provisional constitution-makers. For example, in 1990, the Hungarian Constitutional Court established that the right to social security (Article 70E of the Constitution) "does not entitle anyone to social security and safety, and legal claims on such a general level cannot be defined." " As one Hungarian constitutional expert suggests, "the interpretation of Chief Justice Sólyom clearly states that social and economic rights are not raised to the rank of subjective rights that can be enforced by the judiciary against the state." 78

But the fact that socioeconomic rights cannot be directly enforced by the courts (in the sense an individual cannot claim his or her socioeconomic right through a judicial process) does not prevent these rights from becoming grounds for constitutional challenges to laws and policies exercised in the process of abstract judicial review. Indeed, the dominant opinion in postcommunist constitutional doctrine is that all constitutional provisions, including those which contain socioeconomic rights, can be used as a yardstick to assess the constitutionality of statutes. ${ }^{79}$ As a result, constitutional courts have been quite

76. LUDWIKOWSKI, supra note 18 , at 230.

77. Osiatynski, supra note 29, at 267 n.78 (quoting Decision 31/1990); see also László Sólyom, Introduction to the Decisions of the Constitutional Court of the Republic of Hungary, in CONSTITUTIONAL Judiciary IN A New Democracy: The Hungarian CONSTITUTIONAL COURT 1, 36 (László Sólyom \& Georg Brunner eds., 2000).

78. Péter Paczolay, Human Rights and Minorities in Hungary, 3 J. CONST. L. IN E. \& CENT. EUR. 111, 121 (1996).

79. Zbigniew CZeszejko-Sochacki et AL., Komentarz do Ustawy o Trybunale KONSTYTUCYJNYM [COMMENTARY ON THE LAW ON THE CONSTITUTIONAL TRIBUNAL] (1996) (receiving the authoritative backing of three justices of the Polish Constitutional Tribunal who also authored the book). A breach of a "programmatic norm" (including those that proclaim socioeconomic rights, the details of which are to be spelled out by legislators) happens when "the legislator incorrectly interpreted a provision of the Constitution which defines a particular goal or task of public 
active in reviewing, and at times invalidating, statutes under the standards of socioeconomic rights even though they often call for judgments of social and economic policies in which judges have neither the expertise nor the authority to provide adequate review. ${ }^{80} \mathrm{~A}$ view that these rights are merely programmatic, and thus nonjusticiable ${ }^{81}$ has never become a dominant, recognized doctrine. ${ }^{82}$ On the other hand, it is significant that, when the constitutional courts in the region have a choice to strike down a law under a general constitutional clause such as "social justice" or "equality" on the one hand, or a specific welfare right on the other, they usually opt for the former solution. ${ }^{83}$ This is a symptom of a certain malaise over the direct enforcement of socioeconomic rights. If, however, constitution-makers had opted for a solution under which welfare interests of the citizens belonged to the category of constitutional "targets" with the clear implication that they are not cognizable by the courts, much clarity might have been gained..$^{84}$

authorities, and in particular, has enacted a statute which provides for such measures which cannot lead to that goal and thus breached constitutional liberties or rights." Id. at 163.

80. Perhaps the best known example of this practice is a series of decisions in 1995 by the Constitutional Court of Hungary striking down several laws that made up an austerity policy package (the "Bokros" package, named after the then-Hungarian Minister of Finance). Among other laws, the court invalidated, inter alia, changes to maternity and family support, reductions to household allowances and state subsidized sick leave, and a raise to the interest rate on state loans to homebuilders. For excerpts of the decision, Decision No. 43/1995 of 30 June 1995 concerning social security benefits, see CONSTITUTIONAL JUDICIARY, supra note 77, at 322-32. For a discussion of this decision, see SCHWARTZ, supra note 18, at 92-93; Bugaric, supra note 2, at 265-66; András Sajó, How the Rule of Law Killed Hungarian Welfare Reform, 5 E. EUR. CONST. REV., Winter 1993, at 31. As another example, consider the Bulgarian Constitutional Court's Decision No. 12/1997 of 25 Sept. 1997, described in 3 BULL. ON CONST. CASE L. 357 (1997) and originally published in Bulgarian in Darzhaven Vestnik, issue No. 89 (1997). In this decision the court invalidated provisions of the Pension Act as inconsistent with the right to work. The Provisions had stated that pension entitlement shall be withdrawn from all pensioners that have an earned income. For a third example, consider Decision K 8/96 of 17 July 1996 of the Polish Constitutional Tribunal invalidating a law that prohibited the indexation of pensions. 2 Orzecznictwo Trybunalu Konstytucyjnego [Decisions of the Constitutional Tribunal] 46 (1996), described in Constitution Watch, 5 E. EUR. CONST. REV., Winter 1996, at 17-18.

81. JON Elster ET AL., InSTITUTIONAL DESIGN IN POST-COMMUNIST SOCIETIES 87 (1998); A.E. Dick Howard, The Indeterminacy of Constitutions, 31 WAKE FOREST L. REV. 383, 409 (1996).

82. The evolution of the official doctrine of the Constitutional Tribunal (CT) of Poland is significant. Earlier, before the democratic transition of 1989, the CT articulated a doctrine that so-called "programmatic" provisions of the constitution could not be used as independent grounds for a review. See Decision K 7/89 (1989); Decision K 1/88 (1988). With time, however, the CT abandoned this doctrine and rejected the view that some constitutional provisions are "merely" programmatic and hence unsuitable to serve as a basis for decisions of invalidation of statutes for unconstitutionality. See Decision K 4/95 (1995).

83. See Venelin I. Ganev, Bulgaria: The (Ir)Relevance of Post-Communist Constitutionalism, in Democratic Consolidation, supra note 18 , at 186, 198.

84. See Mark Tushnet, TAKing the Constitution Away from the Courts 169-72 (1999) (advocating constitutional welfare rights that are not enforceable by courts). 
III

\section{Citizens' Duties}

The second striking difference between the U.S. Bill of Rights and postcommunist constitutions is the absence in the former, and presence in the latter, of citizens' duties alongside their rights. ${ }^{85}$ This is not unusual against the background of the European constitutional tradition. ${ }^{86}$ Whether citizens' duties belong in a constitution depends upon the broader conception of what a constitution should be. If the main function of a constitution is seen as placing limits on the exercise of state power, then the inclusion of citizens' duties in its text is illogical and may even be harmful. If, however, the constitution is seen as a statement of the paramount moral and political principles upon which the political system is built, and which are supposed to be subsequently articulated and concretized in ordinary laws, then citizens' duties should be spelled out in the constitution alongside citizens' rights, even if only to counteract what many deem an excessive emphasis on rights to the detriment of responsibilities in liberal democracies.

Different answers to the question of the constitutional status of citizens' duties can, therefore, be seen as resulting from different philosophies about the role of a constitution. These conclusions also result from different conceptions of the relationship between constitutions and subconstitutional laws. If the relationship is seen as one of continuity between general and concrete legal provisions, then the constitution should spell out the bases for legislative regulation of individual duties. But if the relationship is seen as a tension between an act which constrains the legislative will (constitution) and that which gives expression to that will (ordinary legislation), then constitutional duties are redundant.

A survey of postcommunist constitutions in CEE countries indicates that all but three ${ }^{87}$ of the constitutions of the region contain provisions placing affirmative duties upon citizens. There is no correlation between the absence of citizens' duties in the constitution and a more liberal approach to constitutionalism or politics in the three constitutions that constitute exceptions to the general rule.

85. On the silence of the U.S. Constitution regarding matters of duty, see Ralph Nader, The Individual as Citizen, in THE UNITED STATES CONSTITUTION: ROOTS, RIGHTS, AND RESPONSIBILITIES 339, 339 (A.E. Dick Howard ed., 1992); W. Kent Davis, Answering Justice Ginsburg's Charge that the Constitution is "Skimpy" in Comparison to Our International Neighbors: A Comparison of Fundamental Rights in American and Foreign Law, 39 S. TEX. L. REV. 951, 986 (1998).

86. See generally LuDWIKOWSKI, supra note 18, at 230; R.R. Palmer, The Revolutionary Constitutions of Eighteenth-Century Europe, in ROOTS, RIGHTS, AND RESPONSIBILITIES, supra note 85, at 75, 80-81. For an example of duties in a contemporary European constitution, see SPAIN CONST. art. 30(1) (declaring that citizens have "the right and the duty to defend Spain") (emphasis added); id. at art. 31(1) (declaring that citizens have the duty to pay taxes); id. at art. 35(1) (declaring that citizens have the duty to work).

87. Albania, Bosnia and Herzegovina, and Latvia. 
By far, the most frequently articulated constitutional duty is care for the quality of the environment (in fifteen constitutions of the region) ${ }^{88}$ closely followed by the duties of parents to nurture and educate their children (in fourteen constitutions) ${ }^{89}$ and the duty to perform military service (in fourteen constitutions, ${ }^{90}$ although, in six of these, this duty is modified by the right to conscientious objection $^{91}$ ). The next most popular duty is the citizens' obligation to contribute to public expenditures through the payment of taxes (thirteen constitutions). ${ }^{92}$ In eight of the constitutions of the region there exists a child's duty to care for his or her old and infirm parents. ${ }^{93}$ Less common duties include assistance to the state and society in cases of natural or other disasters (three constitutions) ${ }^{94}$ and-perhaps most unsettling - a general duty of loyalty, either to the "constitutional system of government," nally, in Bulgaria there is a unique, and worrying, duty of all to learn and use the official language. ${ }^{97}$ This requirement necessarily raises the issue of minority members' rights.

As this brief survey indicates, the duties included in postcommunist constitutions may be divided into two separate categories: (1) those that are capable of being further concretized into specific legal rules, which then become the actual basis for enforcement of specific obligations, and (2) those that have merely a symbolic character and that do not ground any specific, legally enforceable

88. Belr. CONST. art. 55; Bulg. CONST. art. 55; CroAt. CONST. art. 69; CzECH ReP. ChARTER art. 35; EST. CONST. art. 53; GEOR. CONST. art. 37; LiTH. CONST. art. 53; MACED. CONST. art. 43; Mold. CONST. art. 59; POL. CONST. art. 86; Russ. CONST. art. 58; SlOVK. CONST. art. 44; SlOVN. CONST. art. 72; UKR. CONST. art. 66; MONT. CONST. art. 19.

89. Belr. Const. art. 32; Bulg. CONST. art. 47; Croat. Const. art. 63; Czech ReP. Charter art. 32; Est. CONST. art. 27; Hung. CONST. art. 67; MACED. CONST. art. 40; MOLD. CONST. art. 48; ROM. CONST. art. 44; RuSs. CONST. art. 38; SLOVN. CONST. art. 54; UkR. CONST. art. 51; MonT. CONST. art. 59; SERB. CONST. art. 29.

90. Belr. Const. art. 57; Bulg. COnST. art. 59; CroAt. CONST. art. 47; Est. Const. art. 24; Hung. CONST. art. 70/H; Lith. CONST. art. 139; MACED. CONST. art. 28; MOlD. CONST. art. 57; POL. CONST. art. 85; ROM. CONST. art. 52; RUSS. CONST. art. 59; UKR. CONST. art. 65; YugOSLAVIA CONST. art. 63; SERB. CONST. art. 51. In addition, the Slovak Constitution proclaims cryptically that the defense of the Slovak Republic is "the duty and matter of honor of citizens." SLOVK. CONST. art. 25(1).

91. CROAT. CONST. art. 47; EST. CONST. art. 124; POL. CONST. art. 85; RUSS. CONST. art. 59. Articles $70 / \mathrm{H}$ and 139 of the Hungarian and Lithuanian constitutions, respectively, contain this as an implicit right, suggesting that the duty of protection of the state can be fulfilled by non-military service.

92. Belr. CONST. art. 56; Bulg. CONST. art. 60; CROAT. CONST. art. 51; HunG. CONST. art. 70/I; Maced. Const. art. 33; Mold. CONST. art. 58; POL. CONST. art. 84; RoM. CONST. art. 53; Russ. CONST. art. 57; UKR. CONST. art. 67; YugOSLAVIA CONST. art. 64; MONT. CONST. art. 49; SeRB. CONST. art. 52

93. Belr. Const. art. 32; CROAt. COnSt. art. 63; MACEd. CONST. art. 40; Mold. Const. art. 48; RUSS. CONST. art. 38; UKR. CONST. art. 51; MONT. CONST. art. 59; SERB. CONST. art. 29.

94. Bulg. CONST. art. 61; MONT. CONST. art. 51; SERB. CONST. art. 54.

95. EST. CONST. art. 54(1).

96. Article 82 of the Polish Constitution is typical: "Loyalty to the Republic of Poland, as well as concern for the common good, are the duty of every Polish citizen." For similar articulations of generalized, state-based duties, see GEOR. CONST. art. 44; MOLD. CONST. art. 56; ROM. CONST. art. 50(1).

97. "Bulgarian citizens have the right and obligation to study and use the Bulgarian language." Bulg. Const. art. 36(1). 
obligations. As for the first category, the duties to care for the environment (or, more specifically, not to pollute and damage the environment in any way), to perform military services, or to pay taxes are evident examples of the obligations that a state can legitimately impose upon an individual. The constitutional duty per se, however, cannot be the ground for a specific state decision. Instead, the decision must be grounded in a clear statutory regulation. As such, constitutional duty can be seen as authorizing the legislator to issue specific statutory regulations providing for the duties. For example, no one can be forcibly enlisted in the army in the absence of any legal regulations other than a constitutional statement requiring such a duty. But then, a statutory regulation's usefulness may be put in doubt because the implication might be that the legislator may impose upon an individual only such duties as are generally recognized in the constitution. This clearly is not the case. Consider, as an example, that a duty to inform about crimes committed exists in all criminal codes of the region, even though such a duty is not explicitly constitutionally grounded. As for the second category of constitutional duties, of which the duty of loyalty to the state is an example, they clearly have only an expressive value and are not enforceable in any way other than through the specific legal obligations provided by statutes (for example, the criminal prohibition on treason).

One can go a step further, however, and claim not merely that constitutional provisions on duties are innocuous redundancies, but that they can be harmful for the reasons that I have put forward elsewhere. ${ }^{98}$ First, the provisions on duties diminish the civil-libertarian flavor and introduce a statist rhetoric to the constitutions. The message is that, while the state has some duties toward its citizens, the citizens have duties not just to one another, but also to the state. This message emerges, for instance, in Article 82 of the Polish Constitution: "Loyalty to the Republic of Poland, as well as concern for the common good, are the duty of every Polish citizen." Second, and more important, the inclusion of duties alongside rights might be seen as implying that the enjoyment of one's rights is conditional upon the performance of one's duties. Although this is never explicitly stated, it may be one way of interpreting the reason behind the inclusion of duties in the constitution. But such an implication is, of course, anathema in a liberal theory of citizens' rights where no one surrenders his or her rights (in particular, no one surrenders all one's rights) by a nondischarge of one's duties. Third, the "correlation of rights and duties" view may be seen as a residue of the old, communist approach to constitutional law, which emphasized the so-called interdependence of "rights" and "duties." Strictly understood, however, this connection of rights and duties implies only that one cannot effectively enjoy one's rights if others do not perform their correlative duties. This does not amount to a normative position that one must be denied the enjoy-

98. Wojciech Sadurski, Rights and Freedoms Under the New Polish Constitution: Reflections of a Liberal, 1997 ST. LOUIS-WARSAW TRANSATLANTIC L.J. 91, 99-100 (arguing that this redundancy can be costly). 
ment of one's rights as a result of nonperformance of his duties (including the duty to respect other people's rights).

Whether such an implication is permitted by a constitution is a matter of speculation. To some extent, this question depends upon the structure of the constitutional text: If citizens' duties are grouped in a separate subdivision, as is the case in only three constitutions, ${ }^{99}$ then the thesis about rights' enjoyment being contingent upon performance of duties is more difficult to sustain than when duties are spelled out together with specific rights. More importantly, the very nature of rights and duties in question may render such an implication more or less plausible.

For example, if parental duties and rights are closely connected in a constitutional text, ${ }^{100}$ then it is plausible to argue that such a connection implies that parents who are grossly negligent toward their children surrender the right to make decisions about their children's education and upbringing. Under this circumstance, nonperformance of a duty might result in nonenjoyment of a right. A contrasting situation is illustrated with regard to rights and duties concerning a clean and healthy environment: ${ }^{101}$ The exclusion of a negligent citizen from the benefit of a public good such as clean air is virtually impossible. But there is a third category of cases in which the benefit protected by a right is not a public good and therefore exclusion is physically possible. In such instances, exclusion would be grossly unfair even if a person had not fulfilled his corresponding duties. For example, should a citizen who has not fully discharged her duties to "assist the state and society in the case of natural or other disaster"102 be denied state assistance when she falls victim to just such a disaster?

Again, it is not suggested that the very fact of constitutionalizing citizens' duties implies that the drafters intended to make the enjoyment of rights contingent upon the fulfillment of duties. The fact, however, that such an implication is plausible, at least with regard to some pairs of rights and duties, is a cost that is not offset by any clear benefit gained from proclaiming citizens' duties in the constitution.

\section{CONSTITUTIONAL STANDARDS OF STATUTORY RESTRICTIONS OF RIGHTS}

The U.S. Bill of Rights articulates rights as if they are absolute, and the task of establishing the limits on their lawful exercise is left to the legislature as reviewed by the judiciary courts. The constitutional text does not provide any

99. Moldova's, Poland's, and Romania's.

100. Consider, as an example, Article 63(1) of the Croatian Constitution: "Parents shall have the duty to bring up, support, and educate their children, and have the right and freedom to independently decide on the upbringing of their children."

101. Consider, as an example, Article 37(3) of the Georgian Constitution: "All have the right to live in a healthy environment and use natural and cultural surroundings. All are obligated to protect the natural and cultural surroundings."

102. BULG. CONST. art. 61. 
clear standards for the boundaries of "the freedom of speech, or of the press," the right "to a speedy and public trial," 104 or on what bases legal classifications of citizens infringe "the equal protection of the laws." 105 Whether any particular subconstitutional rules conform with these apparently absolute textual prohibitions on the exercise of legislative and executive power is for the courts to decide. The European constitutional tradition is different in this respect. In continental European constitutions, and in international instruments such as the ECHR, rights provisions are accompanied by guidelines about the constitutionally permitted grounds of statutory limitations of rights. These guidelines do not fully dispose of the role of official interpreters (including constitutional courts) in assessing whether a statutory provision conforms to constitutional rights (as the guidelines regarding permissible limitations are not self-evident and are subject to interpretation), but the interpreters' role is indeed more narrow.

This continental European model has been adopted in all postcommunist constitutions in CEE countries: Not one opted for a Bill of Rights model of absolute prohibitions. Nevertheless, within this European "model" there are different formats of structuring the relationship between the rights provisions and the provisions on the limits to the rights. It is not inconsequential which specific format is chosen. If we imagine a field of possible solutions as a spectrum, one extreme being a constitution that contains no guidelines about permissible limits to rights (in the U.S. fashion), and the other extreme being an imaginary constitution that authorizes the legislature to restrict rights in any way it deems fit (without establishing any substantive criteria for the permissibility of such restrictions), then we can construct a typology of postcommunist constitutional bills of rights. Using this spectrum, these bills of rights fall into three categories.

In the first category are constitutional charters of rights that contain no general clause authorizing the legislature to restrict constitutional rights under certain conditions, but instead mention in specific provisions that those particular rights can be restricted on certain named grounds. The four constitutions that belong to this category ${ }^{106}$ seem to imply that the rights which are not accompanied by permission for legislative restrictions cannot be legislatively restricted at all, an attribute which renders them in this respect similar to the U.S. Bill of Rights. In turn, those constitutional provisions that state that a right is capable of legislative restriction vary the list of permissible reasons for such a restriction. This approach is similar to the construction adopted in the German constitution. ${ }^{107}$ For instance, Article 22(1) of the Georgian Constitution states that

103. U.S. CONST. amend. I.

104. U.S. CONST. amend. VI.

105. U.S. CONST. amend. XIV, $\S 1$.

106. The constitutions of Bosnia and Herzegovina, Georgia, Lithuania, and Montenegro.

107. Compare, F.R.G. CONST. art. 5(2) (stating that freedom of expression can be subject to limitations by statutes for the "protection of young persons" and for the protection of "personal respect"), with id. at art. 10(2) (stating that privacy of letters, posts, and telecommunications may be restricted by 
there is a right to move freely. Then, subsection (3) of the same article continues: "Restriction of these rights is permitted only in accordance with the law, in order to guarantee what is necessary for the existence of a democratic society, state or public security, a strong defense, the prevention of crime or the achievement of justice." In contrast, attached to Article 24(1), a provision regarding "the right to freely receive and disseminate information" is a restriction to the right based on "state security, territorial integrity, the prevention of crime, the defense of rights and dignity of others, the prevention of disclosure of the information, recognized as confidential, or for the guarantee of the independence and impartiality of the court." ${ }^{108}$

It should be added that, although the general practice in these constitutions is to state reasons for permissible restrictions, some articles provide that a restriction may be made by law only, but give no restraining reason why. This approach arguably allows rights to be limited for any reason at all and, in effect, relegates these specific rights to the category of unlimited legislative discretion, thereby depriving them of strong constitutional entrenchment. ${ }^{109}$

The second category of constitutional restrictions covers five other constitutions which, while containing general clauses for limiting rights, state that these clauses apply only to the rights provisions that expressly allow for statutory restrictions. ${ }^{110}$ A typical clause for this model reads: "The rights and freedoms of man and the citizen shall be restricted only by the equal rights and freedoms of others and in instances provided for in the present Constitution." "111 This again results in a situation where the individual articles offer specific justifications and limitations on restrictions to the right in question. With respect to the scope of legislative discretion, the practical effect of these two categories of constitutional constructions of legislative restrictions is identical. A real difference made by a technique of constitutional drafting can be seen between the first two categories, on the one hand, and the third category of constitutions, on the other. This third category clearly prevails in CEE countries and includes all of the region's constitutions except for the nine belonging to the first two catego-

statutes in order "to protect the free democratic order or the existence or security of the Federation"), and with id. at art. 11(2) (stating that freedom of movement may be restricted by statutes when necessary to protect the free democratic order, to combat the danger of epidemics, to deal with natural disasters or grave accidents, to protect young people, or to prevent crime).

108. GEOR. CONST. art. 24(4).

109. As examples of such rights provisions in the first category of constitutions, consider the right to strike in Article 51 of the Constitution of Lithuania: "(1) Employees shall have the right to strike in order to protect their economic and social interests. (2) The restrictions of this right, and the conditions and procedures for the implementation thereof shall be established by law." Another example is found in the constitutional treatment of the right to vote. GEOR. CONST. art. 28; LITH. CONST. art. 20.

110. MACED. CONST. art. 54; SERB. CONST. art. 11; SlOVN. CONST. art. 15; UKR. CONST. art. 64; YUgOSLAVIA CONST. art. 9. The same construction was envisaged by the (then-aborted) project of Charter of Rights in Poland in 1992. See supra note 36. The project explicitly stated, "The rights and liberties guaranteed by this Charter may be restricted only by statute and only when such a restriction is envisaged by this Charter." Draft of the Charter, supra note 36, at art. 5.2.

111. Yugoslavia CONST. art. 9 (emphasis added). 
ries. In these constitutions, permission for statutory restrictions of rights is contained in a general clause that lists the general reasons under which any constitutional right provisions may be limited. These clauses typically have the following form: "Restriction of personal rights and liberties shall be permitted only in the instances specified in law, in the interest of national security, public order, the protection of the morals and health of the population, as well as rights and liberties of other persons." ${ }^{112}$ The list of grounds for restriction varies somewhat: Some lists are narrow; ${ }^{113}$ others refer to international human rights standards for restrictions to rights. ${ }^{114}$ Certain constitutions belonging to this category also list a requirement that limitations must be proportionate to the aim for which they are imposed. ${ }^{115}$ At the most extreme end of the spectrum of constitutional permission for statutory limitations of rights, coming close to the quasi-absolute legislative discretion, we find clauses which make it clear that the constitutional list for grounds of restrictions is not exhaustive and that there may be more grounds than those explicitly mentioned. ${ }^{116}$

The fact that all of the constitutions belonging to this third category have general restricting clauses does not prevent them from listing also, in specific rights provisions, the reasons why these particular rights can be limited. Such provisions are, however, an addition to, rather than an exemption from, the general clause. Some of these particular articles simply repeat a criterion for restrictions set forth in the general clause, restricting the limitation of that right to the criteria which are relevant to the particular situation in which a restriction of a right may plausibly occur. ${ }^{117}$ What, however, renders the third category of constitutions distinct from the first two categories is that, in addition to the particular grounds for restrictions applying to particular rights, there is also a general clause which operates in a blanket fashion on all constitutional rights and liberties.

112. BELR. CONST. art. 23(1). For similar clauses in other constitutions, see ALB. Const. art. 17; Belr. Const. art. 23; CroAt. Const. art. 16; CZECh ReP. ChARTER art. 4 (2, 3, 4); Est. Const. art. 11; Hung. CONST. art 8(2); LAT. CONST. art. 116; Mold. CONST. art. 54; POL. CONST. art. 31, Rom. CONST. art. 49; RUSS. CONST. art. 55; SLOVK. CONST. art. 13.

113. For instance, the Estonian Constitution mentions only "necessity in a democratic society" and the requirement that restrictions not "distort the nature of rights and liberties." EST CONST. art. 11.

114. For instance, the Albanian constitution provides, inter alia, that rights limitations may not exceed the limitations provided for in the ECHR. ALB. CONST. art. 17(2).

115. MOLD. CONST. art. 54(2); ROM. CONST. art. 49(2).

116. E.g., MOLD. CONST. art. 54(1) ("The exercise of certain rights or freedoms may be restricted only under the law and only as required in cases like: the defense of national security, of public order, health or morals, of citizens' rights and freedoms, the carrying of the investigations in criminal cases, preventing the consequences of a natural calamity or of a technological disaster.") (emphasis added).

117. Consider the following two examples. Article 29 of the Moldovan Constitution provides the following grounds for restricting a right to inviolability of the domicile: execution of an arrest warrant, preventing a threat to life, physical integrity, or property of a person, and preventing the spread of a disease. By contrast, Article 26 of the Albanian Constitution envisages the following grounds for limiting the right against forced labor: execution of a judicial decision, performance of military service, or service resulting from a state of war, a state of emergency, or a natural disaster. This is a way in which the Albanian Constitution fleshes out a vague general clause, Article 17, to specific fact situations where limits on a particular right may be relevant. 
A special character within the criteria listed by general clauses is a requirement that a limitation must not strip away the essential quality of a right. This "essential quality" may be constitutionally defined as "the essence" of a right, ${ }^{118}$ "the essence and significance" of the right, ${ }^{119}$ "the existence" of that right or liberty, ${ }^{120}$ or the "nature" of the right which must not be distorted. ${ }^{121}$ If one allows for vagaries of translations into English, the differences are insignificant. What is important is the very idea, influenced by the German approach, that there is a "core" of a right which must not be affected, even if the criteria for constitutionally permissible limitations are scrupulously observed. None of the constitutions spell out any further criteria for what the "essence" consists of, and the task of fleshing out this notion is left to the official interpreters and, in particular, to constitutional courts. Significantly, there is a partial overlap between the countries which have activist, strong constitutional courts and countries whose constitutions have a "non-infringement of the essence of a right" clause. If one puts some exceptions to one side, ${ }^{122}$ one has to acknowledge that the "essence" clause has been a significant constitutional device in checking legislative discretion in restricting the constitutional rights. ${ }^{123}$

Three criteria for legislative limitations of rights cut across the above typology of constitutions. These criteria deserve special mention because they have played an important role in the judicial review of statutes under rights' provisions. The first criterion, already mentioned, is that limitations on rights and freedoms must be nondiscriminatory and therefore must "apply in the same way to all cases that meet the specified condition." must be proportionate to their aim. ${ }^{125}$ The third requirement is that rights can be established only by statute, thus excluding the possibility of restricting constitutional rights by executive action. ${ }^{126}$ This final requirement is widely present and has served as an important basis for many constitutional court decisions. ${ }^{127}$

118. Alb. CONST. art. 17(2); POL. CONST. art. 31(3).

119. CZECh ReP. CHARTER art. 4(4); Hung CONST. art. 8(2); SLOVK. Const. art. 13(4).

120. MOLD. CONST. art. 54(2); ROM. CONST. art. 49(2).

121. EST. CONST. art. 11.

122. For example, Albania has an "essence" proviso in Article 17(1) of its constitution, but it also has a relatively weak constitutional court.

123. For example, one of the most important decisions of the Hungarian Constitutional Court-that the death penalty is unconstitutional-was based, inter alia, on the argument that such penalty necessarily intrudes upon the essential right to life. Decision 23/1990, Oct. 31, 1990, reprinted in CONSTITUTIONAL JUDICIARY, supra note 77, at 118-38.

124. CZeCh ReP. ChARTER art. 4(3); MACED. CONST. art. 54(3); Slovk. Const. art. 13(3).

125. Alb. COnST. art. 17(1); Mold. Const. art. 54(2); Rom. CONST. art. 49(2).

126. E.g., Alb. CONST. art. 17; CZech ReP. ChARTER art. 4(1); Mold. COnST. art. 54(1); Pol. CONST. art. 31(3); ROM. CONST. art. 49(1); SLOVK. CONST. art. 13(2).

127. As examples, consider some decisions of the Croatian and Lithuanian constitutional courts. In 1998, the court in Croatia invalidated a provision of the Law on Railroads, which gave the Minister of Transport a right to determine whether, in the case of strike, the workers had to work during the strike. The court found the provision contrary to the principle that restrictions on the right to strike must be specified by statute, Decision No. CRO-1988-3-015 (July 15, 1998), summarized in 3 BULL. ON CONST. CASE L. 401 (1998). The Croatian Court made similar decisions with regard to analogous provisions on 
What conclusions can be drawn from the classification of constitutional approaches to statutory restrictions of constitutional rights? Offhand, a purely textual analysis might suggest that constitutions in the first category (specific grounds for restrictions attached to particular rights; no general clause of restrictions) and in the second category (general clause of restrictions applies only to those particular rights which explicitly allow for such a restriction) are preferable-from the point of view of the standards of protection of citizens' rights-to constitutions in the third category (general clause specifying the grounds for restrictions which apply to all constitutional rights). This conclusion is because legislative discretion, seen usually as an important threat to individual rights, ceteris paribus, is more restricted in the first two types of constitutions than in the third one. ${ }^{128}$ It may be claimed that, when a legislator has a constitutional mandate to restrict any constitutional rights under the generally and necessarily vaguely formulated grounds for restrictions, the entrenchment value of constitutional rights is largely illusory, creating merely a set of general guidelines, subject to further legislative elaboration based solely on the legislature's views concerning the requirements of national security, public morals, or other matters. Moreover, it can be claimed that, ceteris paribus, the first category offers a superior protection to citizens' rights, because the list of grounds upon which those rights are statutorily restrictable is narrowly tailored to a specific subject-matter of a given right, thus limiting the risk of arbitrary and excessive restrictions to rights.

Strangely enough, this a priori speculation is not confirmed by the constitutional reality of postcommunist democracies in CEE. There is no discernible correlation between the typology of constitutions offered in this section and the level of rights' protection in statutes under constitutional regimes that mandate legislative limitations of rights. The first and second categories of constitutions both occur in states that have a reasonably high level of legislative protection of rights (Slovenia, Lithuania) and in those that have a much less enviable legislative record (Serbia and Georgia). The same can be said about the third cate-

striking within the areas of post and telecommunication services, Decision 98/1998, 2434-2437 (July 15, 1998), in Narodne Novine, and electrical enterprises, Decision No. CRO-1999-3-014 (Oct. 5, 1999), summarized in 3 BULl. ON CONST. CASE L. 355 (1999). The same court decided in 1999 that a provision of the Law on Public Assembly, which allowed local self-government bodies to designate places where public assembly could be held, was unconstitutional because only the national legislator could restrict the constitutional right to public assembly, Decision No. CRO-1999-1-004 (Mar. 31, 1999), summarized in 1 BULl. ON CONST. CASE L. 33 (1999). The Constitutional Court of Lithuania invalidated a number of statutory provisions on the basis that they would allow for restrictions of constitutional rights by legal means other than statutes, for example: the law on restoration of property, which would mandate the government to establish conditions for the restoration of the ownership of land, Decision (Oct. 26, 1995), available at http://www.lrkt.lt/1995/n5a1026a.htm; the law on state secrets which would allow the government to approve the list of state secrets, Decision (Dec. 19, 1996), available at http://www.lrkt.lt/1996/n6a1219a.htm; and the laws on tobacco and alcohol control, which would authorize the government to determine what an advertisement for tobacco or alcohol is, and thus be subject to prohibition under the ban on advertising of tobacco and alcohol products, Decision (Feb. 13 1997), available at http://www.lrkt.lt/1997/n7a0213a.htm.

128. See, e.g., Osiatynski, supra note 25 , at 152-55. 
gory, in which we find countries of widely differing standards of legislative rights protection. Overall, they are not significantly inferior to the standards in countries belonging to the first category.

There are two explanations for this apparent anomaly. One is that the correlation would occur if all other things (other, that is, than the constitutional design of rights' limitations) were equal; obviously they are not, and those other factors are more significant than the structure of the constitution. It is impossible to completely list these other factors in this article. They include, however, both formal institutional factors (the powers and modes of constitutional courts) and the legal and political culture of the community. What becomes clear is that this particular constitutional variable turns out to be relatively insignificant in affecting the shape of the system of legislative protection of rights.

The second explanation is more complex. Consider the first category of constitutions again: Some particular rights are accompanied by clauses about their statutory limitations; others are not. It might appear that those which are framed as "absolute" rights must never be subject to statutory limitations. But this is obviously not the case; the rights in the U.S. Bill of Rights (which, after all, do not have their grounds for permissible restrictions spelled out in the constitutional text) are not "absolute." Scrutiny of a statutory limitation on a right that is formulated in an absolutist manner cannot appeal to constitutional grounds for restrictions, but it does not follow that such scrutiny can never be undertaken, or that it can never conclude with upholding a statutory limitation. For instance, statutory restriction on speech may be interpreted as not restricting the right to freedom of speech, as the freedom will be constructed in a more narrow sense than a license to speak what one wishes without any restraints.

It does not follow that it is insignificant which of the constructions of the statutory limits on rights is chosen. The significance, however, is not in the degree of protection for a right but rather in the modality of arguing about the consistency (or inconsistency) of a statutory limitation with a constitutional right. The reasoning of legislators, and/or of constitutional courts, is more structured, so to speak, when any limitation of a right must be matched to a standard provided by the constitution itself, such as "public security" or public health, with additional requirements of proportionality, nondiscrimination, or noninfringement of the "essence." If a constitution does not supply these yardsticks, much depends on the power of the constitutional court. When the constitutional court is weak and deferential, legislators have more discretion in deciding what restrictions on rights are appropriate than in a system where these standards are constitutionally determined. On the other hand, where constitutional courts are activist and robust, the construction in the first two categories above empowers the courts to a higher degree than is the case in category three. Namely, they are not bound by constitutional guidelines detailing how to reason about the plausibility of statutory restrictions on rights. Either way, the ultimate strength of protection of rights is only indirectly affected by a chosen model of constitutional construction of statutory limits on constitutional rights. 


\section{CONCLUSION}

New democracies of CEE-like post-Second World War Western European states-have embraced the major tenets of constitutional protection of human rights, of which the U.S. Bill of Rights was the first great historical instrument. Breaking with their pre-1989 past, CEE countries have all written into their constitutions strong, unambiguously worded catalogues of human rights that are directly enforceable and binding upon all state institutions and ensured to be supreme over legislation by a system of judicial review.

But the specific way in which constitutionalization of rights has been adopted in CEE is quite different from the U.S. design. First, by incorporating into their constitutions catalogues of socioeconomic rights, which are by necessity under-enforceable, postcommunist democracies failed to clearly distinguish between "classical" rights and policy guidelines. Second, most of the CEE constitutions proclaimed citizens' duties alongside their rights. Third, these postcommunist constitutions provided explicitly for the grounds upon which constitutional rights may be limited by legislation. These three features of postcommunist constitutional rights are not new to Europe; indeed, they are characteristic of a number of constitutions of democratic and nondemocratic Western European countries. Each of these features has its potential benefits as well as risks. Including socioeconomic rights in the constitutions entrenches a task for the governments to care for the poorest and the most needy, but, at the same time, implicates constitutional courts in decisions about socioeconomic policy and risks weakening the enforcement of other, more "classical" rights. Proclaiming constitutional duties is a reminder to the citizenry about civic responsibilities and the duty to contribute to the common good, but at the same time may imply an illiberal doctrine that the enjoyment of constitutional rights is conditional upon the exercise of specific constitutional duties. Finally, spelling out grounds for restrictions of rights may be useful in structuring (and thus constraining) the legislators' (and courts') reasoning about the grounds for limiting the rights, but, on the other hand, it may also erode the significance of the entrenched rights themselves when interpreted as creating a strong legislative mandate to qualify and restrict constitutional rights. Including socioeconomic rights therefore contains a risk of excessive majoritarianism (understood as the power of majority insufficiently mindful of the interests of minorities) in articulating and enforcing vague constitutional provisions, and it erodes the value of constitutional entrenchment.

Within the general model of constitutionalizing the rights, which includes socioeconomic rights, explicit constitutional grounds for rights restrictions, and constitutionalizing citizens' duties, there are certain differences among the countries considered here as to the specific ways of constitutional drafting in these three respects. What is curious about postcommunist constitutionalism is that certain commonsensical speculations about the connections between the 
differences in constitutional drafting and the broader socioeconomic context simply do not get vindicated. For instance, one would speculate that the constitutions with lengthier catalogues of socioeconomic rights, or those where rights are formulated as enforceable rights indistinct from negative liberal rights, would be more enthusiastic towards economic state interventionism, and less likely to favor liberal market policy. This is not the case. Or, one would speculate that the countries which proclaim constitutional duties are more "statist" or communitarian than those few which do not constitutionalize citizens' obligations. This is not the case either. Finally, one might speculate that the countries which constitutionally allow for rights' restrictions only when specific rights' provisions mandate legislatures to do so on exhaustively listed grounds would have a better score of rights protection than those whose constitutions contain general clauses allowing for restriction of all rights on certain vague grounds. None of this speculation is confirmed by the practice of legislation and enforcement of rights in postcommunist countries.

The general conclusion one can draw from these apparent anomalies is that the constitutional charters of rights in postcommunist states of CEE do not matter all that much in affecting the actual shape of the protection of constitutional rights. These countries have constitutions and constitutional bills of rights, but they lack deep constitutionalism, understood as a state of affairs in which constitutions matter greatly in the life of societies. Much more significant variables are extraconstitutional: the sense of integrity and responsibility of legislators, their actual commitment to individual rights, the strength and independence of institutions such as constitutional courts, ombudsmen, and ordinary courts, the level of political culture in the community at large, and many other factors. Their analysis, however, is beyond the scope of this article. 


\section{APPENDIX}

Central and East European postcommunist countries and their Constitutions considered in this article.

Albania - Constitution promulgated on 28th November 1998

Belarus - Constitution adopted 1st March 1994

Bosnia and Herzegovina - Constitution of November 1995 (annex to the Dayton agreement)

Bulgaria - Constitution adopted 12th July 1991

Croatia - Constitution adopted December 1990

Czech Republic - Constitution adopted 16th December 1992 (The Charter on Fundamental Rights was also adopted as part of the Constitutional order of the Czech Republic on this date. $)^{129}$

Estonia - Constitution adopted 28th June 1992

Georgia - Constitution adopted 24th August 1995

Hungary - Constitution adopted 20th August 1949, with numerous amendments Latvia - Constitution adopted in 1922, but significantly amended in 1998

Lithuania - Constitution adopted on 25th October 1992

Macedonia - Constitution adopted 17th November 1991, but amended on 6th January 1992

Moldova - Constitution adopted 29th July 1994

Poland - Constitution adopted 2nd April 1997 and confirmed by referendum October 1997

Romania - Constitution adopted December 1991

Russia - Constitution adopted by referendum 12th December 1993

Slovakia - Constitution adopted 1st September $1992^{130}$

Slovenia - adopted 23rd December 1991 (with small amendments on 14th July 1997 and 25th July 2000)

Ukraine - Constitution adopted 28th June 1996

The Federal Republic of Yugoslavia - Constitution adopted 27th April 1992

Republic of Montenegro - Constitution adopted October 1992

Republic of Serbia - Constitution promulgated September 1990

129. See supra note 69.

130. Id. 